Sains Malaysiana 50(5)(2021): 1393-1405

http://doi.org/10.17576/jsm-2021-5005-18

\title{
Anti-Tumor Activity of Metformin in Human Epidermal Growth Factor Receptor 2 Positive Breast Cancer Cells
}

(Aktiviti Anti-Tumor Metformin pada Reseptor Faktor Pertumbuhan Epidermis Manusia 2 Positif Sel Kanser Payudara)

\author{
Fathul HudA*, Sari EkaWati, Anindy Putri Addina, AHMad FARied, Afiat Berbudi, Taofik Rusdiana, \\ TENNy PUtRI, NuRul QOMARILla, LUKMAN HiLfi, IWAN SETIAWAN \& MUHAMMAd HASAN BASHARI
}

\begin{abstract}
Breast Cancer $(B C)$ is the leading cause of cancer death in women. One BC subtype is very aggressive with amplification of human epidermal growth factor receptor 2 (HER2) protein. Although specific HER2+ targeting agents are available, most of HER $2+B C$ patients develop resistant to these agents. Recent studies show that metformin, is able to become anti-tumor in various cancer cells. This research aims to evaluate anti-tumor activities of metformin to HER $2+B C$ cells in both sensitive and resistant to trastuzumab. A series of assays were performed to evaluate metformin anti-tumor activities in HCC-1954 and SKBR-3 HER2+BC cells. MTT assay was performed to evaluate cell death, and inhibitory concentration $\left(I C_{50}\right)$, while scratch assay was performed to assess inhibition of cell migration and clonogenic assay to assess cell proliferation. $p<0.05$ was considered to be significant. Metformin could suppress the number of HER $2+$ $B C$ cells. Viability assay showed suppression of viable cells after metformin incubation of 60 and $600 \mu M$ compared to control, 30 and $90 \%$, respectively. Surprisingly, IC ${ }_{50}$ of metformin was smaller in HER2+BC HCC-1954 cells that resistant to trastuzumab compare to the sensitive one (SKBR-3). Both were below $1 \mu M$, with $R^{2}$ more than 0.95. Additionally, clonogenic assay showed less colony number and colony area with at least $p<0.05$ in colony number and $p<0.01$ in the area. In addition, metformin inhibited cell migration of HER2+BC cells. Metformin shows a potency as anti-tumor by inducing cell death, inhibiting cell proliferation and cell migration of HER $2+B C$ cells.
\end{abstract}

Keywords: Breast Cancer; HER2+; metformin; Trastuzumab resistant

\section{ABSTRAK}

Kanser Payudara (BC) adalah penyebab utama kematian akibat barah pada wanita. Satu subjenis BC sangat agresif dengan penguatan protein reseptor 2 faktor pertumbuhan epidermis manusia (HER2). Walaupun agen sasaran HER2 + khusus ada, kebanyakan pesakit HER2 + BC mengalami ketahanan terhadap agen ini. Kajian terbaru menunjukkan bahawa metformin mampu menjadi anti-tumor pada pelbagai sel barah. Penyelidikan ini bertujuan untuk menilai aktiviti anti-tumor metformin kepada sel HER $2+B C$ dengan sensitif dan tahan terhadap trastuzumab. Satu siri ujian dilakukan untuk menilai aktiviti anti-tumor metformin pada sel HCC-1954 dan SKBR-3 HER2 + BC. Ujian MTT dilakukan untuk menilai kematian sel dan kepekatan penghambatan $\left(I C_{50}\right)$, sementara ujian awal dilakukan untuk menilai penghambatan penghijrahan sel dan pengujian klonogenik untuk menilai percambahan sel. $p<0.05$ dianggap signifikan. Metformin dapat menekan bilangan sel HER $2+$ BC. Ujian daya maju menunjukkan penekanan sel yang berdaya maju setelah inkubasi metformin 60 dan $600 \mu \mathrm{M}$ berbanding kawalan, masing-masing 30 dan 90\%. Anehnya, IC50 metformin lebih kecil pada sel HER2 + BC HCC-1954 yang tahan terhadap trastuzumab dibandingkan dengan sel sensitif (SKBR-3). Kedua-duanya berada di bawah $1 \mu \mathrm{M}$, dengan R2 lebih daripada 0.95. Selain itu, ujian klonogenik menunjukkan bilangan koloni dan kawasan koloni yang kurang dengan sekurang-kurangnya $p<0.05$ pada bilangan koloni dan $p<0.01$ di kawasan koloni. Sebagai tambahan, metformin menghalang penghijrahan sel HER2 + BC sel. Metformin menunjukkan potensi sebagai anti-tumor dengan mendorong kematian sel, menghambat percambahan sel dan penghijrahan sel HER2+ sel BC.

Kata kunci: HER2 +; kanser payudara (BC); metformin, rintangan Trastuzumab 


\section{INTRODUCTION}

Breast cancer (BC) is becoming one of the main causes of death in the world, in 2012 it causes around 8.2 million deaths (Ferlay et al. 2015). According to the data from Population-based-cancer registration in Indonesia, BC ranks first as the most common death causing cancer in women with an incidence rate of $18.6 \%$, and fifth in all death due to cancer cases (Wahidin et al. 2012).

$\mathrm{BC}$ is a malignancy of the breast tissues that may come from either the ductal epithelium or the lobules. Risk factor for breast cancer varies greatly, from inherited genetic factor (most common), hormones, lifestyle, to environment. In several tumors and cancers, mutation and pathological over-expression of normal growth factor receptor can be found. One of such cases is the Human Epidermal Growth Factor Receptor 2 (HER2), that controls growth, proliferation, and healing of breast cells. HER2 gene synthesizes HER2 protein, which is a receptor in breast cells (Hacioglu et al. 2015). However, in around $25 \%$ of BC patient, HER 2 is provoking multiplication or amplification and called HER2 enrich or HER2+ (Cobleigh et al. 1999).

HCC-1954 cell line was generated from BC patient and has been proven to be resistant intrinsically to trastuzumab. While SKBR-3 cell line is a trastuzumab sensitive HER $2+$ BC cells, with large epithelial types and often found in human breast glands, metastatic tissues, and also cells in pleural effusion (Holliday \& Speirs 2011).

The main strategies of $\mathrm{BC}$ management are still centered on surgeries and systemic therapy. Surgery is the earlier treatment of choice in BC. In systemic therapy, arrays of choices are available, starting from hormonal therapy estrogen hormones, chemotherapy, to targeted therapy, such as trastuzumab for HER2+. Trastuzumab is standard therapy for HER2+ BC patients. However, treatment with trastuzumab is costly and possess the risk of cardiotoxicity that increases the possibility of heart failure. Furthermore, some patients develop resistance in trastuzumab therapy, thus, this problem makes it harder to treat BC HER2+ patient (Sharma et al. 2010).

In a study by Kasznicki et al. (2014), beside as an anti-diabetes mellitus type 2 therapeutic agent, metformin can also inhibit tumor cell proliferation as observed in prostate, liver, and pancreas tumor cells. The mechanism of action of metformin in cancer is still under investigation. It's mechanisms in inhibiting tumor cell proliferation were thought to occur by: AMP kinase pathway activity, sensory cellular energy pathway; and reducing insulin resistance, that can reduce cancer growth factor (Viollet et al. 2012). A preclinical study suggests a direct antineoplastic activity (Cazzaniga et al. 2009).

In this study, we want to investigate the antitumor activity of metformin towards HER2+ BC cell in trastuzumab resistant cells, HCC-1954, and trastuzumab sensitive cells, SKBR-3, using a series of assays e.g. MTT assay, migration assay, and clonogenic assay.

\section{MATERIALS AND METHOdS}

\section{MATERIALS}

Dulbecco's Modified Eagle's Medium was purchased from Gibco, USA. 3-[4,5-dimethylthiazol-2-yl]-2,5 diphenyl tetrazolium bromide (MTT), and trypan blue were purchased from Sigma-Aldrich, USA. Metformin was a gift from PT Kimia Farma. All the other chemicals were of analytical grade purchased from Merck, USA.

\section{CELL CULTURE AND CONDITIONS}

Different human BC cells were used in this study. HCC1954 and SKBR-3 cells (both HER2+) were used. HCC1954 cells were given by Prof. Stefan Wiemann (DKFZ, Germany) and SKBR-3 cell were given by Prof. Andreas Trumpp (DKFZ, Germany). In addition, Luminal A BC cells, MCF-7 and triple negative BC (TNBC) cells, MDAMB 231 were also used. MDA-MB 231 cells were given by Prof. Stefan Wiemann (DKFZ, Germany). All cells were cultured using Dulbecco's Modified Eagle's Medium with supplementation of $10 \% \mathrm{FBS}$ and $1 \%$ streptomycin penicillin. Cells were incubated under a controlled temperature of $37^{\circ} \mathrm{C}$ and $5 \% \mathrm{CO}_{2}$. All cells were between passage range 2 and 20. A summary of breast cancer cell line characteristics that were used are listed in Table 1 (Subik et al. 2010).

TABLE 1. Characteristic of receptors in various breast cancer cell lines (Subik et al. 2010)

\begin{tabular}{lccccc}
\hline & ER & PR & HER2 & subtype & Trastuzumab \\
\hline MCF-7 & 6 & 6 & $0-1+$ & Luminal A & -unrelated \\
MDA MB-231 & 0 & 0 & $0-1+$ & Basal & -unrelated \\
HCC-1954 & 0 & 0 & $3+$ & HER2 & Resistant \\
SKBR-3 & 0 & 0 & $3+$ & HER2 & Sensitive \\
\hline
\end{tabular}


TRYPAN BLUE EXCLUSION ASSAY

A standard protocol was used. Briefly, cells were seeded into 6-well plate and incubated for $24 \mathrm{~h}$ before treated with indicated concentrations of metformin. Cells then were harvested, stained with trypan blue and counted under a microscope at 0 and $72 \mathrm{~h}$ after treatment (Strober 2015).

\section{CYTOTOXICITY ASSAY}

The cytotoxic effect of metformin was evaluated in BC cells using MTT assay, modified from our previous study (Bashari et al. 2016; Rezano et al. 2013). Briefly, cells were seeded into 96-well plate, and then treated with indicated metformin concentrations ( $1 \%$ DMSO as control) on the next day, followed by incubation for $72 \mathrm{~h}$ (in $5 \% \mathrm{CO}_{2}$ at 37 $\left.{ }^{\circ} \mathrm{C}\right)$. MTT solution was then added and incubated for $4 \mathrm{~h}$, followed by addition of DMSO to dissolve the formazan crystal. Absorbance was measured at the wavelength of $450 \mathrm{~nm}$ for finding percentages of viable cells on treated cells compared to the control cells. All tests were carried out at least 3 times in triplicate.

\section{CLONOGENIC ASSAY}

To evaluate anti-proliferative effect of metformin, we analyze plating efficiency (PE) and area per seed according to the previous study using clonogenic assay or colony formation assay (Franken et al. 2006). Briefly, $100 \mathrm{BC}$ cells were seeded on 6-well plate. After attachment, they were treated or untreated (control) with metformin or DMSO $1 \%$ in fresh complete medium, respectively, and incubated for 2 weeks. On the last day, after medium removal, cells were fixed using methanol for $5 \mathrm{~min}$ followed by staining with crystal violet for 3 min then rinsing with tap water (Franken et al. 2006).

The number of the colonies formed were counted manually by measuring each of colony using a ruler. A colony was counted if the diameter measured more than 1 $\mathrm{mm}$. The formula for calculating PE is as follow

$$
\mathrm{PE}(\%)=\frac{\text { number of colony formed }}{\text { number of cells seeded }} \times 100 \%
$$

The area of colonies were calculated semi-automatically by scanning the plate, then measuring the area using Colony Area plugin in ImageJ software (NIH, USA) (Guzmán et al. 2014). The formula for calculating the area per cell seeded is as follow

$$
\text { Area per seed }\left(\mathrm{mm}^{2}\right)=\frac{\text { total area of colony formed }}{\text { number of cells seeded }}
$$

\section{SCRATCH ASSAY}

Consistent equal scratch with perpendicular angle and equal scratch pressure was performed (at $80 \%$ confluence, in plate 24 well) using $200 \mu \mathrm{L}$ pipette tip. Plate then was washed slowly with phosphate buffer solution (PBS) twice to remove dirt and detached cells. Fresh medium was added afterwards. For control group, a complete medium were given without metformin, while for the experiment group were give a complete medium with metformin (2, 60 , or $600 \mu \mathrm{M})$. Cells were incubated in $37^{\circ} \mathrm{C}$ and $\mathrm{CO}_{2}$ $5 \%$ for $48 \mathrm{~h}$.

\section{GAP AREA MEASUREMENT}

Serial observations were done under a microscope. The distance between gap and marking line were the observation point. Image of the gap was captured using a camera connected to microscope and a computer. Gap distances were evaluated quantitatively with ImageJ software (ImageJ 1.50i, National Institutes of Health, USA). Gap areas between borders were determined using image analyzing software that can calculate the distance reached in each time points determined.

\section{COMBINATION INDEX}

Combination index was analyzed using compusyn software (ComboSyn Inc, Paramus, NJ), Two doses (500 and $1000 \mu \mathrm{M}$ ) of metformin were combined with two doses (1 and $4 \mu \mathrm{M}$ ) of docrubicine or paclitaxel. The synergistic effects on cell viability were analyzed.

\section{STATISTICAL ANALYSIS}

Normalization was done to determine absorbance of cell death in each plate using Microsoft Excel program (Microsoft, USA). Drug curves, as well as $\mathrm{IC}_{50}$ was created and predicted using four parametric logistic regression by Sigmaplot ver.12 (SYSTAT Software Inc., USA). All other data were analyzed using Statistical Product and Service Solutions version 22 (SPSS; IBM, USA). To determine the association of inhibition of colony formation by each treatment group, we performed one-way Analysis of Variance (ANOVA) test with post-hoc Least Significance Difference (LSD). The statistical analysis was considered significant if $\mathrm{p}$ value $<0.05$.

\section{RESULTS AND DISCUSSION}

\section{VIABILITY TEST OF SKBR-3 CELL LINE}

First, we evaluated cytotoxic activity of metformin using viability test in HER2+ BC SKBR-3 cells. We incubated 
SKBR-3 cells with metformin for $72 \mathrm{~h}$. Our finding showed that the higher the metformin concentration the higher the cytotoxicity. There were a statistically significant of nonviable cells after metformin incubation of 60 and $600 \mu \mathrm{M}$ compared to control, 30 and 90\%, respectively (Figure 1).

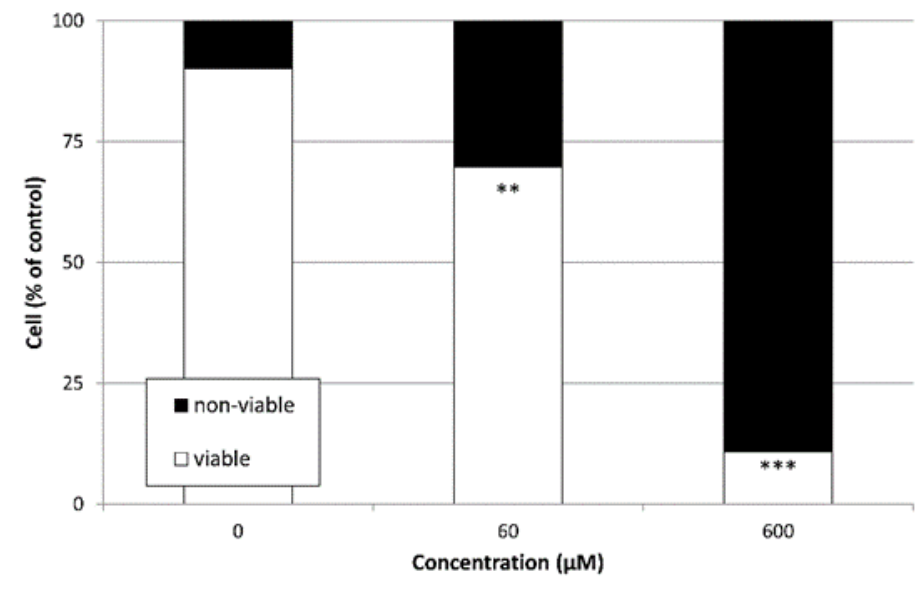

FIGURE 1. Trypan blue exclusion assay $72 \mathrm{~h}$ after incubation. Viable and non-viable cells were calculated. Statistical analysis was done using one-way ANOVA, post-hoc

Tukey HSD. *: $\mathrm{p}<0.05 ;{ }^{* *}: \mathrm{p}<0.01,{ }^{* * *}$ : $\mathrm{p}<0.001$ against control

\section{METFORMIN CAUSES CELL DEATH IN BOTH TRASTUZUMAB RESISTANT AND SENSITIVE BC HER2+ CELLS}

Then, we evaluated cytotoxic activity of metformin using MTT assay of metformin in HER2+ BC cells using MTT assay. We used trastuzumab sensitive HER $2+$, SKBR-3 and trastuzumab resistant HER2+ HCC-1954 cells. Our data showed metformin causes cell death in both trastuzumab resistant and sensitive BC HER $2+$ cells in a dose dependent manner. We then performed four parameter logistics analysis to predict inhibition concentration $50 \%\left(\mathrm{IC}_{50}\right)$. The $\mathrm{IC}_{50}$ of metformin in tested $\mathrm{BC}$ cell lines were less than $1 \mathrm{mM} . \mathrm{IC}_{50}$ of metformin in HCC-1954, and SKBR-3 cells were 600 and $980 \mu \mathrm{M}$, respectively. A very significant $\mathrm{R}^{2}$ value was obtained, for each dose curves are 0.9791 and 0.9723 , respectively (Figure 2). Our data showed that metformin was more sensitive to the trastuzumab resistant HER2 + BC cells than to the trastuzumab sensitive HER2+ $\mathrm{BC}$ cells. Indicating that metformin may overcome the resistance to trastuzumab.

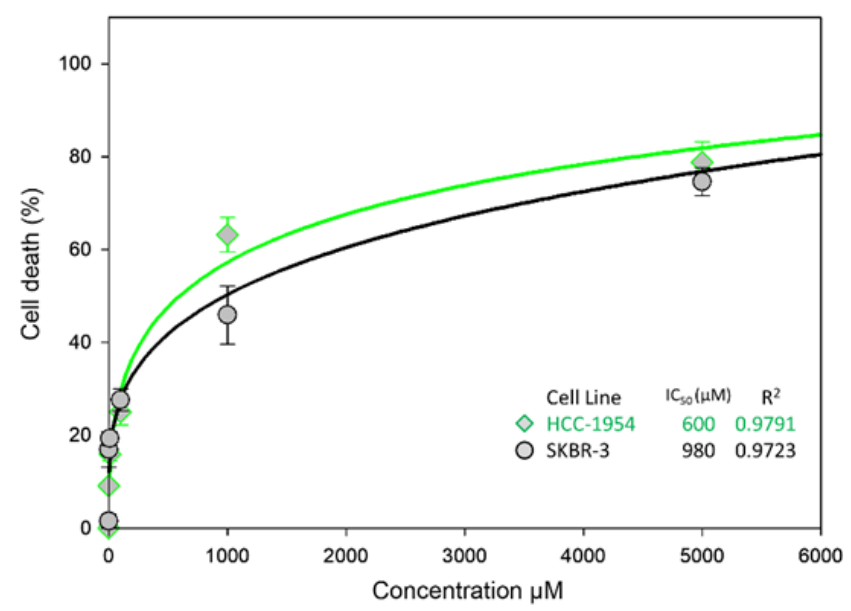

FIGURE 2. Dose response curves of metformin in HER2+ BC cells. Various concentration of metformin were tested. Data was presented as mean, SEM, of triplicate and three individual experiment. HCC-1954, trastuzumab resistant HER2+ (green). SKBR-3, trastuzumab sensitive HER2+ (black). $\mathrm{IC}_{50}$ were calculated using four parameter logistics regression in Sigmaplot ver. 12 


\section{METFORMIN SUPPRESSES CELL PROLIFERATION OF} HER2+ BC CELLS

We analyzed the data of cytotoxic activity of metformin in HER2+ BC cells, and then wondered whether metformin has anti proliferative effect to HER $2+$ BC cells. Therefore, we used clonogenic assay, to assess cell proliferation and colony formation in HCC-1954 as well as SKBR-3 cells.
Data showed that metformin $600 \mu \mathrm{M}$ decreases colony number in HCC-1954 into quarter of control while in SKBR-3 it was one-eight compared to control. The area of colony in $600 \mu \mathrm{M}$ was a quarter of the control in HCC1954 cells and one-fifth of control in SKBR-3 cells (Figure 3). This data was statistically significant as $p<0.01$ in colony number and $\mathrm{p}<0.05$ in the area of colony between treatment and control group.
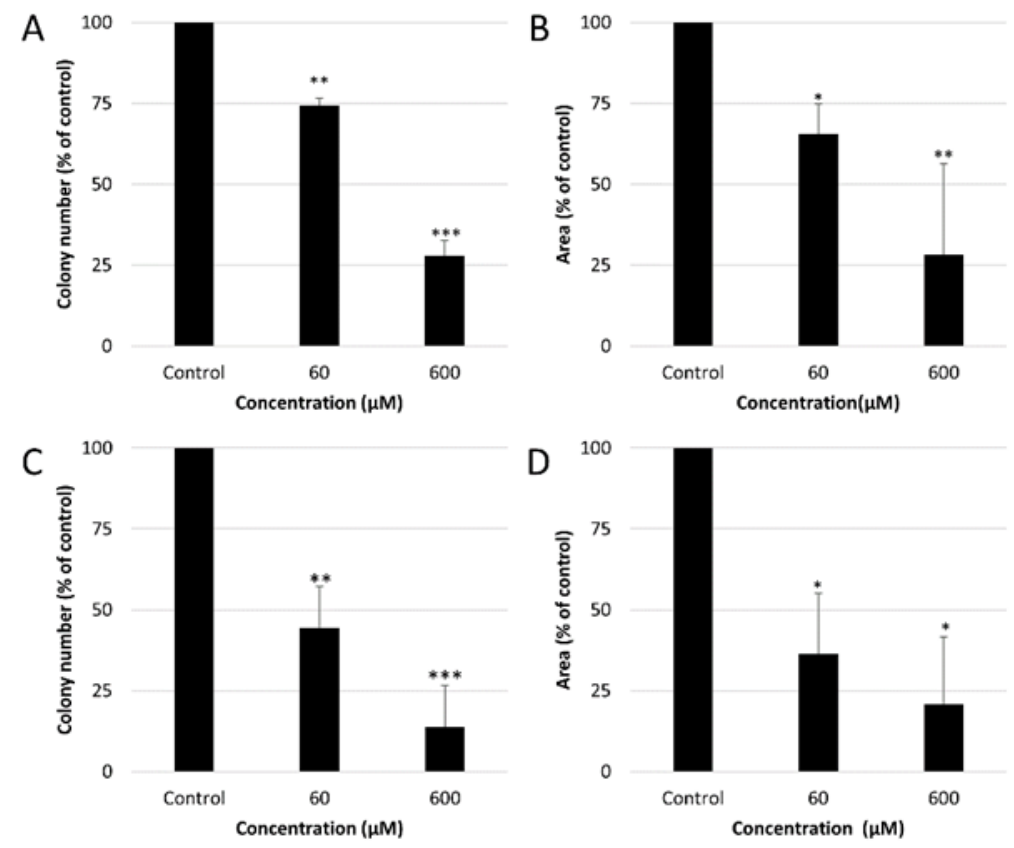

FIGURE 3. Metformin inhibits colony formation of HER2+ breast cancer cells. Metformin concentration were $0,60,600 \mu \mathrm{M}$ and cell were incubated for 3 days, then replace with complete medium and incubate for 14 days. Colonies were fixed and stained with crystal violet. A and B for HCC-1954, C and D for SKBR, A and $\mathrm{C}$ for colony number, $\mathrm{B}$ and $\mathrm{D}$ for area. ANOVA one-way post hoc LSD was performed. *, p $<0.01, * *, p<0.05, * * *, p<0.001$

\section{METFORMIN INHIBITS HER2+ BC CELLS MIGRATION}

To further evaluate anti-tumor activity of metformin, we then evaluated migration inhibition properties of metformin in HCC-1954 and SKBR-3 cells. Our data showed that metformin inhibits $\mathrm{BC}$ cell migration in dose dependent manner. After $48 \mathrm{~h}$ of intervention, $55 \%$ of gap area remains to the initial gap $(0 \mathrm{~h})$ of control group, while in the metformin 2,60 , and $600 \mu \mathrm{M}$, the gap area that remains were 72,76 , and 81\% (respectively) in HCC-1954 cells. In SKBR-3, after $48 \mathrm{~h}$ of intervention, control shows $53 \%$ of gap area remains, but bigger in 2, 60, and $600 \mu \mathrm{M}$, which were 63, 69, and 76\% (respectively). Statistical analysis was done using one way ANOVA followed by post hoc LSD, data of gap areas were statistically significant between any metformin treated groups compared to control (Figure 4). 


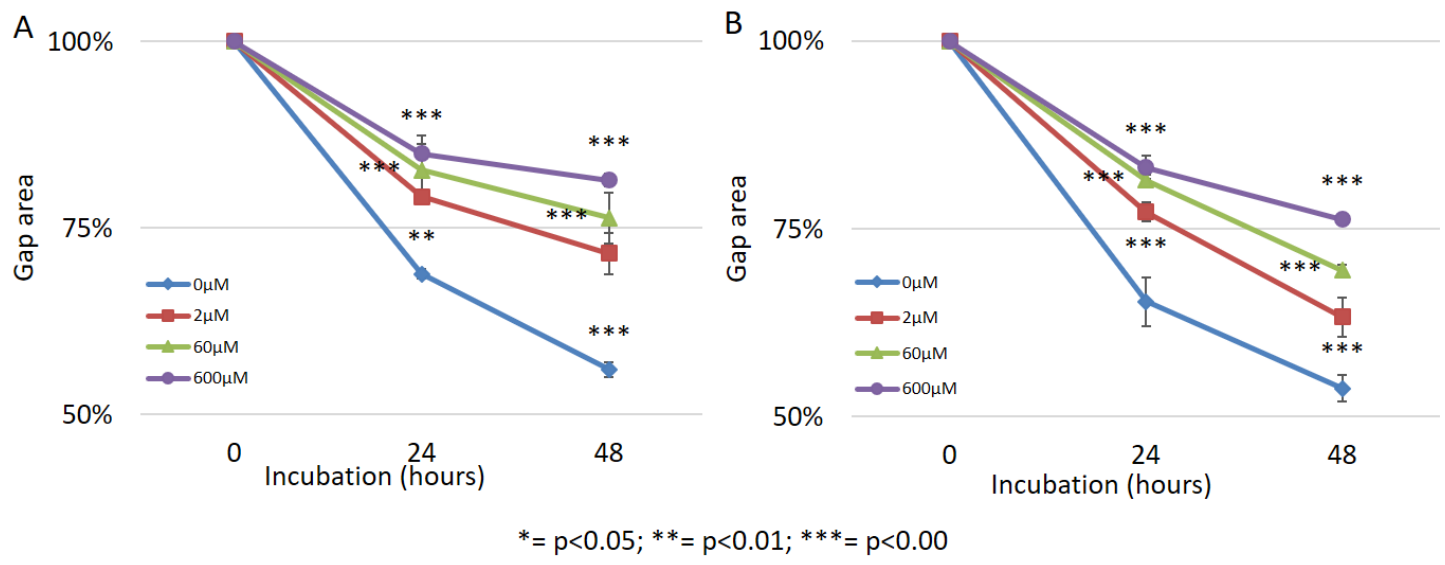

FIGURE 4. Metformin inhibits cell migration of HER2+ BC cells. Metformin concentration were 0, 2, 60, $600 \mu \mathrm{M}$ and cell were incubated for 0, 24, and $48 \mathrm{~h}$. A. HCC-1954, B. SKBR-3. Gaps were capture and measure using ImageJ software. Data was presented as mean \pm SD from duplicate of three individual experiments and analyzed by ANOVA one way, post hoc LSD. *: $\mathrm{p}<0.05 ; * *$ : $\mathrm{p}<0.01, * * *$ :

$$
\mathrm{p}<0.001 \text { against control }
$$

\section{COMBINATION THERAPY WITH PACLITAXEL AND DOXORUBICIN}

We then evaluate metformin activity combined with other chemotherapeutic agents (paclitaxel and doxorubicin). We used 500 and $1000 \mu \mathrm{M}$ metformin with combination of two concentration ( 1 and $4 \mu \mathrm{M})$ of doxorubicin and paclitaxel. Compusyn software was used to analyze the result. Combination index were all less than 1 , means these combinations show a synergistic effect. Indicating that metformin is potentially be used in combination to enhance the effect of paclitaxel or doxorubicin (Figure 5).

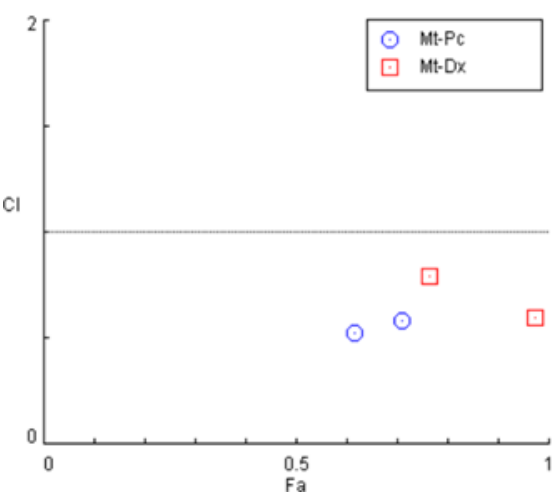

FIGURE 5. Combination index (CI) of Metformin with conventional chemotherapy agent. Metformin (Mt) with Paclitaxel

$(\mathrm{Pt})$ or Doxorubicin $(\mathrm{Dx})$; Fraction affected $(\mathrm{Fa})$ 
Metformin is a well-known and foremost as diabetes mellitus type 2 drug. It is a biguanide compound which has the potential to downregulate insulin via IGF-I signaling pathway, and AMPK pathway (Kasznicki et al. 2014). AMPK activation leads to lower liver and cell glucose production and high insulin sensitivity leads to increase glucose uptake in peripheral tissue. Metformin increases glucose tolerant, avoid hypoglycemia, prevents hyperinsulenemia (Collier et al. 2006). Metformin also considered as a safe drug, abundance in production and stock, good tolerability profile, and low in cost.

The available evidence from basic science, clinical, and population-based research supports the anticancer effect of metformin (Kasznicki et al. 2014). Recent epidemiological and observational studies have shown association between metformin and cancer-related mortality, reduction in cancer incidence, compared with other antidiabetic treatment in diabetic patients (Bowker et al. 2006; Cazzaniga et al. 2013). Metformin is potential as a chemopreventive agent by lowering $31 \%$ overall relative risk from cancer incidence and mortality associated with cancer in type 2 diabetes treated with metformin, compared to diabetes with other treatments (Hadad et al. 2014).

Mechanisms of metformin in cancer prevention are suggested via activation of AMPK/LKB1 pathway, cell cycle arrest, apoptosis induction, protein synthesis inhibition, reduction in insulin level, immune system activation, cancer stem cell eradication, reduced IGF1/
insulin/HER-2 mediated signaling and angiogenesis inhibition (Malek et al. 2013; Pernicova \& Korbonits 2014; Viollet et al. 2012). Activity in AMP kinase pathway for sensory cellular energy which is a cancer growth pathway via an inhibition in respiratory chain complex I and reducing circulating glucose (Gallagher \& LeRoith 2011; Viollet et al. 2012). Insulin resistance reduction, in which insulin itself is a growth reduction factor for cancer, changes insulin-like growth factor level, sex hormones, and adipokinase that contributes in tumorigenesis (Viollet et al. 2012). Some studies have found that the anti-tumor ability of metformin is mediated via p53 dependent pathway (Buzzai et al. 2007). Since p53 communicates with other tumor suppressors (such as AMPK) to coordinate the cell growth during stress as in oxygen and nutrient deprivation, metformin triggers tumor regression In p53 deficient tumor, presumably via autophagy (Buzzai et al. 2007).

In trials of $\mathrm{BC}$ patient with diabetes mellitus showed that combination of metformin with neoadjuvant therapy resulting in increased pathological complete response compared to neoadjuvant alone (Jiralerspong et al. 2009). Anti-tumor effects of metformin and its potential use as a therapeutic agent for breast cancer are started to be shown (Jiralerspong et al. 2009). Another trial showed dual effects of metformin on BC growth related to insulin status (Cazzaniga et al. 2013). Previous studies have been conducted to evaluate cytotoxic effect of metformin in different cancer entities in vitro (Table 2).

TABLE 2. Study of metformin usage as anti-tumor agent, in other various cancer cell lines (excluding breast cancer)

\begin{tabular}{|c|c|c|c|c|}
\hline No & Cancer cell lines & Cell source & $\begin{array}{l}\text { Metformin } \\
\text { Conc } \mathrm{IC}_{50} \\
\text { (micromolar) }\end{array}$ & Reference \\
\hline 1 & $\begin{array}{l}\text { 143B; } \\
\text { MG63; } \\
\text { U2OS }\end{array}$ & Osteosarcoma & $\begin{array}{l}7,290 \\
8,720 \\
9,130\end{array}$ & (Quattrini et al. 2014) \\
\hline 2 & Calu-3 & $\begin{array}{l}\text { Human non-small cell lung carcinoma. K-RAS } \\
\text { G13D } \\
\text { TP53 } \\
\text { CDKN2A }\end{array}$ & 1,000 & (Della Corte et al. 2016) \\
\hline 3 & H1299 & $\begin{array}{l}\text { human non-small cell lung carcinoma. Mutation } \\
\text { NRAS Q61K }\end{array}$ & 1,500 & (Della Corte et al. 2016) \\
\hline 4 & H1975 & $\begin{array}{l}\text { human non-small cell lung carcinoma. Mutation } \\
\text { EGFR }\end{array}$ & 2,500 & (Della Corte et al. 2016) \\
\hline 5 & H358 & $\begin{array}{l}\text { human non-small cell lung carcinoma. Mutation } \\
\text { KRAS G12C }\end{array}$ & 1,000 & (Della Corte et al. 2016) \\
\hline 6 & $\begin{array}{l}\text { ASPC-1; } \\
\text { BxPc-3; } \\
\text { PANC-1; } \\
\text { SW1990 }\end{array}$ & Pancreatic cancer (single dose) & $<5,000$ & (Wang et al. 2008) \\
\hline 7 & JB & Feline injection site sarcoma cell line & 8,000 & (Pierro et al. 2017) \\
\hline
\end{tabular}


Previous studies showed that metformin in micromolar concentration decreases BC cell viability using MTT assay was well as inhibits cell proliferation and cell migration in MDA-MB 231, MCF-7, MDAMB-231, and MDA-MB-435 (Davies et al. 2017; Sharma et al. 2019). Metformin inhibits the development, and promotes the resensitization, of treatment-resistant breast cancer (Davies et al. 2017; Gao et al. 2016; Marinello et al. 2019). Metformin regulates multiple pathways of cancer cells including downregulating multiple proliferation controlling genes, activating mitochondrial pathway of apoptosis via inducing anti-apoptotic genes $\mathrm{BCL}_{2}$ and $\mathrm{Bcl}$ $\mathrm{xL}$, suppressing cell migration regulating proteins such as N-Cadherin and MMPs (Lord et al. 2018; Sharma et al. 2019). Indeed, metformin regulates BC cells metabolism one of which by reducing cholesterol intracellular content that led to an inhibition of cell growth, cell survival and cell movement (Sharma et al. 2019).

Our study showed antitumor potential of metformin in BC. We treated HER2+ BC SKBR-3 and HCC-1954 cells with metformin, and our finding showed that metformin 60 and $600 \mu \mathrm{M}$ trigger more cell death compared to control (Figure 1). Based on the drug curves, $\mathrm{IC}_{50}$ is predicted below $1 \mathrm{mM}$, with good $\mathrm{R}^{2}$ (Figure 2). Colony number and area of colonies also showed that metformin suppressed cell proliferation in HER2+ BC cells (Figure $3)$. Moreover, HER $2+$ cell migration was more prevalent in metformin treated cells using migration assay (Figure 4). Interestingly, the cytotoxic effect, anti-proliferative as well as anti-cell migration of metformin is not only in SKBR-3 cells but also in HCC-1954 cells. HCC-1954 cells are trastuzumab resistant HER2 + BC cell line (Subik et al. 2010). Our data indicate the potency of metformin in overcoming resistance of trastuzumab therapy in trastuzumab resistance HER $2+\mathrm{BC}$ cells.

HER2 + BC subtype is one of the most aggressive and poor prognostic $\mathrm{BC}$ subtype. Although there are available HER2 targeted agents, some BC patients develop resistant to these HER2 inhibitors. The relapse free survival probability of HER2 + BC patients is approximately $50 \%$ while the less aggressive luminal ABC patients is about $80 \%$ (Parker et al. 2009). Amplification of HER2+ gene in BC leads to over activity of HER2 receptor causing uncontrolled cell growth and survival, eventually lead to cancer (Iqbal \& Iqbal 2014). Therefore, our data will open new frontier in treatment of HER2+ BC, that in present time dependent heavily on targeted therapy, shifting to a more basic metabolic drug treatment (Guo et al. 2017; Marcotte et al. 2016).

There are some well-known mechanisms of trastuzumab resistance including mutation of HER2, auto activation of downstream cascade of HER2 and downregulation of HER2. These all mechanisms keep the aggressive profile of HER2 BC cells including fast cell growth and tend to migrate which need a lot of energy. Metformin proposes to overcome indirectly the resistance of trastuzumab by activates AMPK pathways that lead to suppress gluconeogenesis, inhibit cell cycle, and inhibit protein fatty acid synthesis (Deng et al. 2019).

Analysis of genomic and proteomics in HER2positive breast cancer that resistant to trastuzumab showed a deregulation of TRAIL - tumor necrosis factor-related apoptosis-inducing ligand (Diaz-Rodriguez et al. 2019). This is in the future promising as a possibility as treatment target.

A HER 2+ breast cancer cell predicts a poorer prognosis, and higher sensitivity to chemotherapy. HER2 is a receptor of transmembrane tyrosine kinase included in human epidermal growth factor receptor family which function in epithelial cell proliferation and survival. The downstream pathways of HER2 including MAPK and PI3K/Akt (Deng et al. 2019).

Trastuzumab is considered a standard of care for BC. It is a humanized recombinant monoclonal antibody. A resistant in $\mathrm{BC}$ to trastuzumab may include HER3 or EGFR IGF receptor, activation of PI3K/AKT/mTOR, cMET, PTEN, SRC, MUC4, VEGF, p95 (Lavaud \& Andre 2014). Metformin has anti-proliferative effect on trastuzumabresistant breast cancer cells via inhibition of erbB2/IGF receptor interaction (Liu et al. 2011).

In a recent finding metformin may serve as adjuvant to enhance trastuzumab emtansine (T-DM1) to improve clinical efficacy of T-DM1 via caveolin-1 mediated endocytosis (Chung et al. 2018). This open a new hope for tumor chemotherapy. Whether it will work on trastuzumab resistant BC is another research subject.

Vazquez-Martin et al. (2011) using SKBR3 model that has acquired auto-resistance to trastuzumab to assess the effect of metformin. Synergistically metformin interacts with trastuzumab to suppresses self-renewal and proliferation (mammo-sphere size) of BC in both acquired and de novo HER2+ cell. The metformin concentration used is in 1 to hundreds of $\mathrm{mmol}^{-1}$. However, this group just able to obtain proof of principle and still could not elucidate the mechanism behind the findings (MartinCastillo et al. 2010).

In order to avoid overestimation of the potential benefit of experimental anti-BC therapy such as metformin in unselected populations, carrying out neo-adjuvant translational research may identify $\mathrm{BC}$ patients likely to benefit from metformin-based regimens. Metformin is a 'hybrid' anticancer compound that physically combines 
the long-lasting effects of antibodies (by persistently lowering levels of blood insulin and glucose) and the immediate potency of a cancer cell-targeting molecular agent (by suppressing the AMPK/mTOR/p70S6K1 axis and crucial BC-related protein kinases such as HER2) (Martin-Castillo et al. 2010).

Metformin inhibits tumor cell migration via downregulation of MMP2, MMP9 breast cancer cells via the AMPK/mTOR/autophagy pathway (Jang et al. 2014; Li et al. 2017). Metformin-inhibited cell viability, migration, colony, and sphere formations were reversed back by cholesterol treatment. Similarly, cholesterol treatment inverted metformin-reduced several gene expressions. Metformin decreased cell viability, migration and stemness in metastatic MDA-MB-231 cells. Similarly, metformin treatment suppressed expressions of antiapoptotic genes $\mathrm{BCL}_{2}$ and $\mathrm{Bcl}-\mathrm{xL}$, and mesenchymal genes vimentin, N-cadherin, Zeb1, and Zeb2 with simultaneous enhancement of apoptotic caspase 3 and Bax, and epithelial genes E-cadherin and keratin 19 expressions, confirming an inhibitory effect of metformin in tumorigenesis (Sharma et al. 2019).

Having promising data of metformin in HER2+ BC cells, another question arised. We wondered whether metformin has also cytotoxic effect in other BC subtype cells including luminal A and triple negative $\mathrm{BC}$ (TNBC) cells. We then conducted experiments in luminal A MCF7 cells and TNBC MDA MB-231 cells. Cytotoxic assay showed metformin causes cell death in those cell lines. The $\mathrm{IC}_{50}$ of metformin in both $\mathrm{BC}$ cell lines are 900 and $775 \mu \mathrm{M}$ in MCF-7, and MDA MB-231 cells, respectively. A very significant $\mathrm{R}^{2}$ value was obtained, for each dose curves are 0.9304 and 0.9393 , respectively (Figure 6).

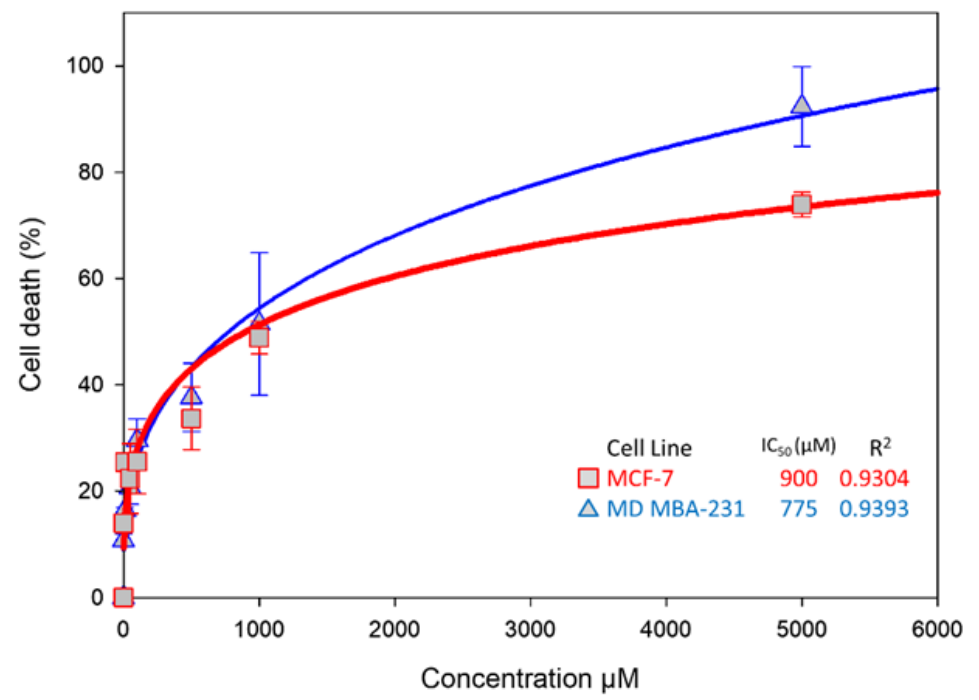

FIGURE 6. Dose response curves of metformin in luminal-A and triple negative BC cells. Various concentration of metformin were tested. Data was presented as mean, SEM, of triplicate and three individual experiments. MCF-7, Luminal A breast cancer cell (red). MDA MB-231, a triple negative breast cancer cells (blue). $\mathrm{IC}_{50}$ were calculated using four parameter logistics regression in Sigmaplot ver. 12

Metformin has been studied for its anti-tumor potency alone or with a combination with other conventional anti- tumor agent. Other studies showed different results on cytotoxicity of metformin in $\mathrm{BC}$ cells. All the $\mathrm{IC}_{50}$ result in $\mathrm{BC}$ cell line between 100 and $10 \mathrm{mM}$ are shown in Table 3 . 
TABLE 3. Study of metformin usage as anti-tumor agent in breast cancer cell lines

\begin{tabular}{ccccc}
\hline No & $\begin{array}{c}\text { Breast Cancer } \\
\text { Cell Lines }\end{array}$ & Breast Cancer Cell Type & $\begin{array}{c}\text { Metformin Conc IC } \\
\text { (microMolar) }\end{array}$ & Reference \\
\hline 1 & BT-474; & Luminal B & 3,000 & (Zhu et al. 2014) \\
& SKBR-3; & HER2 & 3,000 & \\
& MCF10A & Luminal-A & 5,000 & (Liu et al. 2011) \\
2 & BT474; & Luminal B & 10,000 & (Guo et al. 2017) \\
& SKBR-3; & HER2 & 5,600 & \\
& MCF-7; & Luminal A & 4,500 & (Scherbakov et al. 2016) \\
\hline
\end{tabular}

This study focused upon HER2+ BC cell. Using HCC-1954 and SKBR-3 we evaluated the dose curve. The $\mathrm{IC}_{50}$ were below $1 \mathrm{mM}$. To the best of our knowledge, this is the first study that evaluate metformin antitumor activity only on HER2+ BC cell. Furthermore, Our $\mathrm{IC}_{50}$ is lower in concentration compared to other previous studies. Other study using HER $2+$ cell (SKBR-3) has $\mathrm{IC}_{50}$ at least 3 mM (Liu et al. 2011; Silvestri et al. 2015; Zhu et al. 2014).

In other type of $\mathrm{BC}$ cells, we evaluate metformin antitumor activity to luminal $\mathrm{A}(\mathrm{MCF}-7)$ and $\mathrm{TNBC}$ cell (MDA MB-231). The $\mathrm{IC}_{50}$ were below $1,000 \mu \mathrm{M}$. Previous studies using luminal A cell (MCF-7) has $\mathrm{IC}_{50}$ at least 2,500 $\mu \mathrm{M}$ (Guo et al. 2017; Scherbakov et al. 2016; Silvestri et al. 2015; Zhu et al. 2014). In addition, research using TNBC cell (MDA MB-231) has $\mathrm{IC}_{50}$ at least $10,000 \mu \mathrm{M}$, far much higher than our finding (Guo et al. 2017; Silvestri et al. 2015). Other research using luminal B (BT-474) has $\mathrm{IC}_{50}$ at least 3,000 $\mu \mathrm{M}$ (Liu et al. 2011; Zhu et al. 2014).

\section{CONCLUSION}

From previously mentioned data, metformin has been proven to have cytotoxic effects and able to inhibit migratory growth of HER2+ BC cells sensitive and resistant types in regards to trastuzumab therapy. However, we realized several limitations of this study, which are length of study and data replication that was conducted in a very close time range, thus more research and reviews are warranted to be able to obtain a more comprehensive and accurate results.

Further studies need to be gathered before a clinical trial of metformin either as a single agent or in combination with chemotherapeutic agents or with HER2 targeted therapy. A clinical epidemiology intervention study with a strong relationship need to be carried carefully. Then at that time, as it is already easy to obtain and relatively in low price, metformin usage as an anti-tumor agent will be considered a breakthrough in cancer therapy, while at present standard treatment of $\mathrm{BC}$ centered on chemotherapy and other invasive therapy such as tissue removal.

\section{ACKNOWLEDGEMENTS}

This research was supported by Universitas Padjadjaran Fundamental Research Grant No. 855/UN6.3.1/PL/2017 for FH and PKM-PE Grant from Indonesian Directorate of Higher Education at Ministry of Education and Research no $2230-547 / \mathrm{B} 3.1 / \mathrm{KM} / 2017$ for $\mathrm{FH}, \mathrm{APA}$ and SE. We thank to Saras Hidayat and Dliyauddin Fachri, for their technical assistance, and also to Fairuz Putri Azzahra, Luthfi Rahman, Sarah Anjani Putri for their support in PKM-PE. All authors declare has no conflict of interest.

\section{REFERENCES}

Bashari, M.H., Fan, F., Vallet, S., Sattler, M., Arn, M., LucknerMinden, C., Schulze-Bergkamen, H., Zornig, I., Marme, F., Schneeweiss, A., Cardone, M.H., Opferman, J.T., Jager, D. \& Podar, K. 2016. Mcl-1 confers protection of Her2-positive breast cancer cells to hypoxia: Therapeutic implications. Breast Cancer Research 18(1): 26.

Bowker, S.L., Majumdar, S.R., Veugelers, P. \& Johnson, J.A. 2006. Increased cancer-related mortality for patients with type 2 diabetes who use sulfonylureas or insulin. Diabetes Care 29(2): 254-258. 
Buzzai, M., Jones, R.G., Amaravadi, R.K., Lum, J.L., DeBerardinis, R.J., Zhao, F., Viollet, B. \& Thompson, C.B. 2007. Systemic treatment with the antidiabetic drug metformin selectively impairs p53-deficient tumor cell growth. Cancer Research 67(14): 6745-6752.

Cazzaniga, M., DeCensi, A., Pruneri, G., Puntoni, M., Bottiglieri, L., Varricchio, C., Guerrieri-Gonzaga, A., Gentilini, O.D., Pagani, G. \& Dell'Orto, P. 2013. The effect of metformin on apoptosis in a breast cancer presurgical trial. British Journal of Cancer 109(11): 2792-2797.

Cazzaniga, M., Bonanni, B., Guerrieri-Gonzaga, A. \& Decensi, A. 2009. Is it time to test metformin in breast cancer clinical trials? Cancer Epidemiology and Prevention Biomarkers 18(3): 701-705.

Chung, Y.C., Chang, C.M., Wei, W.C., Chang, T.W., Chang, K.J. \& Chao, W.T. 2018. Metformin-induced caveolin-1 expression promotes T-DM1 drug efficacy in breast cancer cells. Scientific Report 8(1): 3930.

Cobleigh, M.A., Vogel, C.L., Tripathy, D., Robert, N.J., Scholl, S., Fehrenbacher, L., Wolter, J.M., Paton, V., Shak, S. \& Lieberman, G. 1999. Multinational study of the efficacy and safety of humanized anti-HER2 monoclonal antibody in women who have HER2-overexpressing metastatic breast cancer that has progressed after chemotherapy for metastatic disease. Journal of Clinical Oncology 17(9): 2639.

Collier, C.A., Bruce, C.R., Smith, A.C., Lopaschuk, G. \& Dyck, D.J. 2006. Metformin counters the insulin-induced suppression of fatty acid oxidation and stimulation of triacylglycerol storage in rodent skeletal muscle. American Journal of Physiology-Endocrinology and Metabolism 291(1): E182-E189.

Davies, G., Lobanova, L., Dawicki, W., Groot, G., Gordon, J.R., Bowen, M., Harkness, T. \& Arnason, T. 2017. Metformin inhibits the development, and promotes the resensitization, of treatment-resistant breast cancer. PLOS ONE 12(12): e0187191.

Della Corte, C.M., Ciaramella, V., Di Mauro, C., Castellone, M.D., Papaccio, F., Fasano, M., Sasso, F.C., Martinelli, E., Troiani, T., De Vita, F., Orditura, M., Bianco, R., Ciardiello, F. \& Morgillo, F. 2016. Metformin increases antitumor activity of MEK inhibitors through GLI1 downregulation in LKB1 positive human NSCLC cancer cells. Oncotarget 7(4): 4265-4278.

Deng, J., Peng, M., Wang, Z., Zhou, S., Xiao, D., Deng, J., Yang, X., Peng, J. \& Yang, X. 2019. Novel application of metformin combined with targeted drugs on anticancer treatment. Cancer Science 110(1): 23-30.

Diaz-Rodriguez, E., Perez-Pena, J., Rios-Luci, C., Arribas, J., Ocana, A. \& Pandiella, A. 2019. TRAIL receptor activation overcomes resistance to trastuzumab in HER2 positive breast cancer cells. Cancer Letters 453: 34-44.

Ferlay, J., Soerjomataram, I., Dikshit, R., Eser, S., Mathers, C., Rebelo, M., Parkin, D.M., Forman, D. \& Bray, F. 2015. Cancer incidence and mortality worldwide: Sources, methods and major patterns in GLOBOCAN 2012. International Journal of Cancer 136(5): E359-E386.

Franken, N.A.P., Rodermond, H.M., Stap, J., Haveman, J. \&
Bree, C.V. 2006. Clonogenic assay of cells in vitro. Nature Protocols 1(5): 2315-2319.

Gallagher, E.J. \& LeRoith, D. 2011. Diabetes, cancer, and metformin: Connections of metabolism and cell proliferation. Annals of the New York Academy of Sciences 1243(1): 54-68.

Gao, Z.Y., Liu, Z., Bi, M.H., Zhang, J.J., Han, Z.Q., Han, X., Wang, H.Y., Sun, G.P. \& Liu, H. 2016. Metformin induces apoptosis via a mitochondria-mediated pathway in human breast cancer cells in vitro. Experimental and Therapeutic Medicine 11(5): 1700-1706.

Guo, Z., Sevrioukova, I.F., Denisov, I.G., Zhang, X., Chiu, T.L., Thomas, D.G., Hanse, E.A., Cuellar, R.A.D., Grinkova, Y.G., Langenfeld, V.W., Swedien, D.S., Stamschror, J.D., Alvarez, J., Luna, F., Galvan, A., Bae, Y.K., Wulfkuhle, J.D., Gallagher, R.I., Rd Petricoin, E.F., Norris, B., Flory, C.M., Schumacher, R.J., O’Sullivan, M.G., Cao, Q., Chu, H., Lipscomb, J.D., Atkins, W.M., Gupta, K., Kelekar, A., Blair, I.A., Capdevila, J.H., Falck, J.R., Sligar, S.G., Poulos, T.L., Georg, G.I., Ambrose, E. \& Potter, D.A. 2017. Heme binding biguanides target cytochrome P450-dependent cancer cell mitochondria. Cell Chemical Biology 24(10): 1259-1275.

Guzmán, C., Bagga, M., Kaur, A., Westermarck, J. \& Abankwa, D. 2014. ColonyArea: An ImageJ plugin to automatically quantify colony formation in clonogenic assays. PLOS ONE 9(3): e92444.

Hacioglu, B., Akin, S., Sever, A.R. \& Altundag, K. 2015. Clinical implications of intratumoral heterogeneity of HER2 gene amplification in locally advanced HER2-positive breast cancer patients. Future Oncology 11(18): $2495-$ 2497.

Hadad, S.M., Hardie, D.G., Appleyard, V. \& Thompson, A.M. 2014. Effects of metformin on breast cancer cell proliferation, the AMPK pathway and the cell cycle. Clinical and Translational Oncology 16(8): 746-752.

Holliday, D.L. \& Speirs, V. 2011. Choosing the right cell line for breast cancer research. Breast Cancer Research 13(4): 215.

Iqbal, N. \& Iqbal, N. 2014. Human epidermal growth factor receptor 2 (HER2) in cancers: Overexpression and therapeutic implications. Molecular Biology International 2014: Article ID. 852748.

Jang, S.Y., Kim, A., Kim, J.K., Kim, C., Cho, Y.H., Kim, J.H., Kim, C.H. \& Lee, J.Y. 2014. Metformin inhibits tumor cell migration via down-regulation of MMP9 in tamoxifenresistant breast cancer cells. Anticancer Research 34(8): 4127-4134.

Jiralerspong, S., Palla, S.L., Giordano, S.H., Meric-Bernstam, F., Liedtke, C., Barnett, C.M., Hsu, L., Hung, M.C., Hortobagyi, G.N. \& Gonzalez-Angulo, A.M. 2009. Metformin and pathologic complete responses to neoadjuvant chemotherapy in diabetic patients with breast cancer. Journal of Clinical Oncology 27(20): 3297-3302.

Kasznicki, J., Sliwinska, A. \& Drzewoski, J. 2014. Metformin in cancer prevention and therapy. Annals of Translational Medicine 2(6): 57.

Lavaud, P. \& Andre, F. 2014. Strategies to overcome trastuzumab 
resistance in HER2-overexpressing breast cancers: Focus on new data from clinical trials. BMC Medicine 12: 132.

Li, W.D., Li, N.P., Song, D.D., Rong, J.J., Qian, A.M. \& Li, X.Q. 2017. Metformin inhibits endothelial progenitor cell migration by decreasing matrix metalloproteinases, MMP2 and MMP-9, via the AMPK/mTOR/autophagy pathway. International Journal of Molecular Medicine 39(5): 12621268.

Liu, B., Fan, Z., Edgerton, S.M., Yang, X., Lind, S.E. \& Thor, A.D. 2011. Potent anti-proliferative effects of metformin on trastuzumab-resistant breast cancer cells via inhibition of erbB2/IGF-1 receptor interactions. Cell Cycle 10(17): 2959-2966.

Lord, S.R., Cheng, W.C., Liu, D., Gaude, E., Haider, S., Metcalf, T., Patel, N., Teoh, E.J., Gleeson, F., Bradley, K., Wigfield, S., Zois, C., McGowan, D.R., Ah-See, M.L., Thompson, A.M., Sharma, A., Bidaut, L., Pollak, M., Roy, P.G., Karpe, F., James, T., English, R., Adams, R.F., Campo, L., Ayers, L., Snell, C., Roxanis, I., Frezza, C., Fenwick, J.D., Buffa, F.M. \& Harris, A.L. 2018. Integrated pharmacodynamic analysis identifies two metabolic adaption pathways to metformin in breast cancer. Cell Metabolism 28(5): 679-688.e4.

Malek, M., Aghili, R., Emami, Z. \& Khamseh, M.E. 2013. Risk of cancer in diabetes: The effect of metformin. ISRN Endocrinology 2013: Article ID. 636927.

Marcotte, R., Sayad, A., Brown, K.R., Sanchez-Garcia, F., Reimand, J., Haider, M., Virtanen, C., Bradner, J.E., Bader, G.D. \& Mills, G.D. 2016. Functional genomic landscape of human breast cancer drivers, vulnerabilities, and resistance. Cell 164(1): 293-309.

Marinello, P.C., Panis, C., Silva, T.N.X., Binato, R., Abdelhay, E., Rodrigues, J.A., Mencalha, A.L., Lopes, N.M.D., Luiz, R.C., Cecchini, R. \& Cecchini, A.L. 2019. Metformin prevention of doxorubicin resistance in MCF-7 and MDA-MB-231 involves oxidative stress generation and modulation of cell adaptation genes. Scientific Report 9(1): 5864.

Martin-Castillo, B., Dorca, J., Vazquez-Martin, A., OliverasFerraros, C., Lopez-Bonet, E., Garcia, M., Barco, S.D. \& Menendez, J.A. 2010. Incorporating the antidiabetic drug metformin in HER2-positive breast cancer treated with neo-adjuvant chemotherapy and trastuzumab: An ongoing clinical-translational research experience at the Catalan Institute of Oncology. Annals of Oncology 21(1): 187-189.

Parker, J.S., Mullins, M., Cheang, M.C.U., Leung, S., Voduc, D., Vickery, S., Davies, S., Fauron, C., He, X. \& Hu, Z. 2009. Supervised risk predictor of breast cancer based on intrinsic subtypes. Journal of Clinical Oncology 27(8): 1160-1167.

Pernicova, I. \& Korbonits, M. 2014. Metformin--mode of action and clinical implications for diabetes and cancer. Nature Reviews Endocrinology 10(3): 143-156.

Pierro, J., Saba, C., McLean, K., Williams, R., Karpuzoglu, E., Prater, R., Hoover, K. \& Gogal, R. 2017. Anti-proliferative effect of metformin on a feline injection site sarcoma cell line independent of Mtor inhibition. Research in Veterinary Science 114: 74-79.
Quattrini, I., Conti, A., Pazzaglia, L., Novello, C., Ferrari, S., Picci, P. \& Benassi, M.S. 2014. Metformin inhibits growth and sensitizes osteosarcoma cell lines to cisplatin through cell cycle modulation. Oncology Reports 31(1): 370-375.

Rezano, A., Kuwahara, K., Yamamoto-Ibusuki, M., Kitabatake, M., Moolthiya, P., Phimsen, S., Suda, T., Tone, S., Yamamoto, Y., Iwase, H. \& Sakaguchi, N. 2013. Breast cancers with high DSS1 expression that potentially maintains BRCA2 stability have poor prognosis in the relapse-free survival. BMC Cancer 13: 562.

Scherbakov, A.M., Sorokin, D.V., Tatarskiy Jr., V.V., Prokhorov, N.S., Semina, S.E., Berstein, L.M. \& Krasil'nikov, M.A. 2016. The phenomenon of acquired resistance to metformin in breast cancer cells: The interaction of growth pathways and estrogen receptor signaling. IUBMB Life 68(4): 281292.

Sharma, A., Bandyopadhayaya, S., Chowdhury, K., Sharma, T., Maheshwari, R., Das, A., Chakrabarti, G., Kumar, V. \& Mandal, C.C. 2019. Metformin exhibited anticancer activity by lowering cellular cholesterol content in breast cancer cells PLoS ONE 14(1): e0209435.

Sharma, G.N., Dave, R., Sanadya, J., Sharma, P. \& Sharma, K.K. 2010. Various types and management of breast cancer: An overview. Journal of Advanced Pharmaceutical and Technological Research 1(2): 109-126.

Silvestri, A., Palumbo, F., Rasi, I., Posca, D., Pavlidou, T., Paoluzi, S., Castagnoli, L. \& Cesareni, G. 2015. Metformin induces apoptosis and downregulates pyruvate kinase M2 in breast cancer cells only when grown in nutrient-poor conditions. PLoS ONE 10(8): e 0136250.

Strober, W. 2015. Trypan blue exclusion test of cell viability. Current Protocols in Immunology 111: A3.B.1-A3.B.3.

Subik, K., Lee, J.F., Baxter, L., Strzepek, T., Costello, D., Crowley, P., Xing, L., Hung, M.C., Bonfiglio, T., Hicks, D.G. \& Tang, P. 2010. The expression patterns of ER, PR, HER2, CK5/6, EGFR, Ki-67 and AR by immunohistochemical analysis in breast cancer cell lines. Breast Cancer 4: 35-41.

Vazquez-Martin, A., Oliveras-Ferraros, C., Del Barco, S., MartinCastillo, B. \& Menendez, J.A. 2011. The anti-diabetic drug metformin suppresses self-renewal and proliferation of trastuzumab-resistant tumor-initiating breast cancer stem cells. Breast Cancer Research Treatment 126(2): 355-364.

Viollet, B., Guigas, B., Garcia, N.S., Leclerc, J., Foretz, M. \& Andreelli, F. 2012. Cellular and molecular mechanisms of metformin: An overview. Clinical science 122(6): 253-270.

Wahidin, M., Noviani, R., Hermawan, S., Andriani, V., Ardian, A. \& Djarir, H. 2012. Population-based cancer registration in Indonesia. Asian Pacific Journal of Cancer Prevention 13(4): 1709-1710.

Wang, L.W., Li, Z.S., Zou, D.W., Jin, Z.D., Gao, J. \& Xu, G.M. 2008. Metformin induces apoptosis of pancreatic cancer cells. World Journal of Gastroenterology 14(47): 7192-7198.

Zhu, P., Davis, M., Blackwelder, A.J., Bachman, N., Liu, B., Edgerton, S., Williams, L.L., Thor, A.D. \& Yang, X. 2014. Metformin selectively targets tumor-initiating cells in ErbB2-overexpressing breast cancer models. Cancer Prevention Research 7(2): 199-210. 
Fathul Huda*, Afiat Berbudi, Iwan Setiawan \& Muhammad Hasan Bashari

Department of Biomedical Science, Faculty of Medicine Universitas Padjadjaran

Bandung 40161

Indonesia

Fathul Huda*, Ahmad Faried, Afiat Berbudi \& Muhammad Hasan Bashari

Oncology and Stem Cell Working Group

Faculty of Medicine

Universitas Padjadjaran

Bandung 40161

Indonesia

Sari Ekawati \&Anindy Putri Addina

Bachelor of Medicine Program, Faculty of Medicine

Universitas Padjadjaran

Bandung 40161

Indonesia

Ahmad Faried

Department of Neurosurgery, Faculty of Medicine

Universitas Padjadjaran

Bandung 40161

Indonesia
Taofik Rusdiana

Department of Pharmaceutics and Pharmaceutical Technology

Faculty of Pharmacy

Universitas Padjadjaran

Bandung 40161

Indonesia

Tenny Putri \& Nurul Qomarilla

Cell Culture Laboratory, Faculty of Medicine

Universitas Padjadjaran

Bandung 40161

Indonesia

Lukman Hilfi

Department of Public Health, Faculty of Medicine

Universitas Padjadjaran

Bandung 40161

Indonesia

*Corresponding author; email: fathul@unpad.ac.id

Received: 18 December 2019

Accepted: 29 September 2020 